\author{
Cadernos de \\ ESTUdOS LINGüĺsTICOS - (56.2), Campinas, Jul./Dez. 2014
}

\title{
O FUNCIONAMENTO DO POLÍTICO NO TEXTO JURÍDICO E NOS POSTS DE BLOGS
}

\author{
FABIANA FERNANDA STEIGENBERGER \\ Universidade Federal de São Carlos \\ SOELI MARIA SCHREIBER DA SILVA \\ Universidade Federal de São Carlos
}

\begin{abstract}
RESUMO: O presente trabalho tem como objetivo verificar o funcionamento do político em posts de blogs e no decreto $\mathrm{n}^{\circ} 6583$ de 29 de setembro de 2008. Por meio das análises tornou-se possível olhar a movimentação do político na linguagem no momento em que cada enunciador do post assume a palavra e expõe sua posição diante do Acordo Ortográfico. Para completar essa análise e termos uma visão mais ampla de todo processo sócio-histórico envolvido nesse contexto, também buscamos verificar o movimento do político no texto jurídico que desencadeou as discussões presentes nos blogs. Dessa forma, podemos observar o político e compreender que os sentidos entram em conflito, se dividem, tornam-se outros. Nessa disputa se constituem os lugares de dizer distribuídos de maneira hierarquizada e desigual para os falantes na enunciação. Essa disputa ocorre permanentemente, pois, segundo Guimarães (2000), o político se dá na linguagem e caracteriza-se como incontornável porque o homem sempre irá falar.
\end{abstract}

Palavras-chave: político; lei; posts

ABSTRACT: This study aims to verify the functioning of political in blog's posts and law 6583 of September 29, 2008. Through the analysis it became possible to look at the political movement of the tongue at the time enunciating each post takes the word and exposes its position before the orthographic agreement. To complete this analysis and have a broader view of the whole process involved in socio-historical context, we also seek to observe the political movement in the legal text that triggered the present discussions on blogs. Thus, we can observe the policy and understand that the way conflict, divide, become other. In this dispute constitute places of saying so distributed hierarchical and unequal to the speakers in the enunciation. Such dispute occurs permanently, because, according to Guimarães (2000), takes place in the political language and characterized as inevitable because man will always talk.

Key-words: political; law; posts

\section{INTRODUÇÃO}

O presente artigo tem como objetivo verificar o funcionamento do político no decreto n 6583 de 29 de setembro de 2008 e em posts de blogs. Selecionamos weblogs que tratam do Acordo Ortográfico de 1990 e o texto do decreto que promulgou o Acordo. Por meio das análises, procuramos olhar a movimentação do político na linguagem no momento em que cada enunciador assume a palavra 
através dos posts e expõe sua posição diante do Acordo Ortográfico. Para completar essa análise e termos uma visão mais ampla de todo processo sócio-histórico envolvido nesse contexto, também buscamos observar o movimento do político no texto jurídico que desencadeou as discussões nos blogs. Dessa forma, podemos analisar o político e compreender que os sentidos entram em conflito, se dividem, tornam-se outros. Ao compararmos o movimento do político nos posts e no decreto, torna-se possível recuperar o apagamento produzido pelo texto jurídico e examinar o litígio, o desentendimento, quando o povo afirma o seu pertencimento no todo. Nessa disputa se constituem os lugares de dizer distribuídos de maneira hierarquizada e desigual para os falantes na enunciação. Essa disputa ocorre permanentemente, pois o político se dá na linguagem e caracteriza-se como incontornável porque o homem sempre irá falar. Para embasarmos nossas análises, recorremos a Rancière (1996) e a Guimarães (2005).

\section{O POLÍTICO EM RANCIÈRE}

Para depreendermos o conceito de político, recorremos a Rancière. Esse estudioso tem se dedicado às áreas de história, filosofia, estética e política. $\mathrm{O}$ autor destaca que a política começa a partir do blaberon, ou seja, do dano.

...a política não se ocupa dos vínculos entre os indivíduos, nem das relações entre os indivíduos e a comunidade, ela é da alçada de uma contagem das 'partes' da comunidade, contagem que é sempre uma falsa contagem, uma dupla contagem ou um erro na contagem. Pois vejamos essas axiai, esses títulos de comunidade (...). Aristóteles enumera três: a riqueza dos poucos (os oligoi); a virtude ou a excelência (areté) que dá seu nome aos melhores (aos aristoi); e a liberdade (a eleutéria) que pertence ao povo (demos). (RANCIÉRE, p. 22, 1996).

Na comunidade, cada parte possui um título: a oligarquia pertence aos ricos, à aristocracia as pessoas de bem e a liberdade ao povo. Entretanto, há um desequilíbrio nessa divisão das partes: a liberdade do povo, pois é uma propriedade vazia - um dano. O povo não possui riqueza, nem virtude e caracteriza-se como "massa indiferenciada daqueles que não têm nenhum título positivo", enquanto que os oligoi e os aristoi, além de serem detentores de seus títulos, também possuem a liberdade. O povo é livre como aqueles que lhes são superiores. Então, a liberdade - qualidade daqueles que não possuem nada, nem o mérito e nem a riqueza - é entendida como virtude comum. "Ela permite ao demos - ou seja, o ajuntamento factual dos homens sem qualidade (...) - identificar-se por homonímia com o todo da comunidade" (RANCIËRE, p. 24, 1996). Chega-se então ao dano: o povo apropria-se da qualidade comum a todas as partes da comunidade como sua própria qualidade. O povo passa a ser a parte sem-parcela, pois o que ele possui os demais também têm.

É a partir dessa constituição que a comunidade torna-se política e está dividida por um litígio fundamental que prejudica a contagem de suas partes. Nessa contagem, o demos sobra e não é contado - representa o dano e não possui parcela na distribuição do bem comum por não oferecer nada de valor a ele. $\mathrm{O}$ 
povo constrói-se como a classe do dano, a qual provoca prejuízo à comunidade $\mathrm{e}$ a institui como comunidade do justo e do injusto. A política, para Rancière, existe a partir dessa divisão dos membros da comunidade, que origina a parte dos semparcela. A política se encontra na oposição vantagem/desvantagem que esconde o dano representado pelo demos.

A política é a esfera de atividade de um comum que só pode ser litigioso, a relação entre as partes que não passam de partidos e títulos cuja soma é sempre diferente do todo. (RANCIÉRE, p. 29, 1996).

A política sempre nega essa parcela dos sem-parcela e apóia-se em um efeito de igualdade entre todas as classes sociais. Portanto, funda-se sobre uma falsidade ao omitir o "lado negativo" da sociedade.

A virtude do demos é a liberdade, que permite ao povo identificar-se à comunidade, ou seja, é a propriedade comum que possibilita a igualdade. O povo apropria-se dessa característica como se ela lhe fosse peculiar e ocasiona uma apropriação indevida do comum, um litígio. E, assim, o povo é a parcela desigual, apesar de se fazer igual, o que gera o litígio e torna a sociedade política.

O litígio, isto é, ter ou não ter valor, efetiva-se pela situação de fala. E, por isso, na constituição da política há ainda outro dano: o povo sem logos (palavra). Essa classe separa-se das demais, porque não possui o logos, enquanto as outras o possuem. Estamos diante de uma grande diferenciação entre os grupos sociais, pois há aqueles que falam realmente (os oligoi e os aristoi) e aqueles cuja a voz apenas imita a voz articulada. Rancière destaca que a destinação política do homem se dá pela posse do logos - da palavra, dotada de manifestação a qual marca a separação entre os que falam e os que não falam. "O que a palavra manifesta, o que ela torna evidente para uma comunidade de sujeitos que a ouvem, é o útil e o nocivo e, consequentemente, o justo e o injusto" (p. 17, 1996). É nessa cisão intermediada pelo logos que se determina o animal lógico e o político. Entre o útil e o justo encontra-se o dano, responsável por instituir a comunidade política como antagonismo de partes da sociedade, que não são as partes reais do corpo social.

Há política porque o logos nunca é apenas a palavra, porque ele é sempre indissoluvelmente
a contagem que é feita dessa palavra: a contagem pela qual uma emissão sonora é ouvida
como palavra, apta a enunciar o justo, enquanto uma outra é apenas percebida como
barulho que designa prazer ou dor, consentimento ou revolta. (RANCIÈRE, p. 36, 1996)

Portanto, na organização da cena política temos um duplo dano cunhado a partir do litígio: a divisão das partes da sociedade considerando-as iguais sendo que há os sem-parcela; e a posse do logos. É por meio do logos que se trava o conflito/desentendimento entre as partes.

Rancière mostra que a sociedade é hierarquizada e vive em conflito, desconstruindo a aparente imagem de igualdade e harmonia presente na forma de pensar a democracia. E, em decorrência dessa conjuntura, nem todos os homens possuem a palavra igualmente. Para assumi-la é necessário ter valor na comunidade, mas sabemos que há os sem-parcela - o demos - que não possuem 
valor e que "falam" mesmo não sendo "compreendidos". A política caracterizase pelo desentendimento, que ocorre porque na comunidade existe uma parte dos sem parte, os desiguais, que se posicionam como iguais e, por não terem valor, não são compreendidos. Todo esse processo litigioso só é possível através da linguagem.

Rancière, ainda, destaca que existem três formulações que apagam o político, denominadas arqui-política, para-política e meta-política. A arquipolítica configura-se a partir de Platão e procura apresentar uma solução lógica ao paradoxo da parcela dos sem-parcela. A pólis passa a ser organizada segundo suas funções: o demos é decomposto, e seus membros, juntamente com os oligoi e os aristoi, são hierarquizados de acordo com o papel realizado na comunidade. A partir dessa estrutura, cada grupo possui apenas o que lhe é próprio ao desempenhar sua função. Os artesãos, por exemplo, participam da comunidade sob a condição de não terem que cuidar do todo. Eles participam da sociedade ao exercerem sua função: sapataria, carpintaria ou outra arte que seja realizada através das mãos. E, também, ao se submeterem às ordens que determinam que executem exclusivamente sua função. O demos é atualizado e deixa de ser a parte dos sem-parcela para constituir-se como aqueles dotados de uma virtude/função específica. Ocorre a "substituição de um título vazio - a liberdade do povo - por

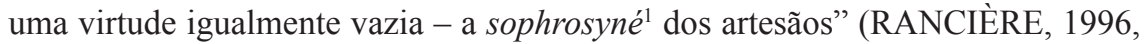
p. 78). Extingue-se o espaço comum que a democracia, por meio da liberdade, proporcionava ao demos para exercer o seu poder. Na arqui-política, a democracia (a falsa política) é substituída pela República.

A figura da para-política é estruturada por Aristóteles e centra-se na disputa pelo poder. Tem-se por princípio a divisão igualitária do poder para que possa ocorrer a alternância entre o governante e os governados.

\begin{abstract}
O demos, por intermédio do qual existe a especificidade da política, torna-se uma das partes de um conflito político que se identifica com o conflito pela ocupação dos "cargos de mando", das arkhai da pólis. (...) A para-política é antes de tudo esse centramento do pensamento político no lugar e no modo da repartição das arkhai pelo qual se define um regime, no exercício de um certo kurion (poder). Esse centramento parece evidente aos olhos de uma modernidade para a qual a questão do político é naturalmente a do poder, dos princípios que o legitimam, das formas nas quais ele se distribui e dos tipos que o especificam. (RANCIÈRE, 1996, p. 80)
\end{abstract}

O litígio permanece sendo a especificidade da política, porém o litígio do demos não se dá mais pelo falso efeito de liberdade, mas por meio da disputa para ocupar os "cargos de mando". A comunidade torna-se capaz de incluir o demos sem experimentar o litígio e liquida-se a parcela dos sem-parcela. Nesse contexto, a para-política constitui-se a partir da disputa pelo poder.

A última figura destacada por Rancière é a meta-política, a que delata o dano originário da política e denuncia a falsa existência da igualdade entre as partes na sociedade. Essa forma de política

${ }^{1}$ Rancière conceitua sophrosyné como a virtude de fazer apenas o seu ofício, a sua função na comunidade. 
é o exercício daquela verdade, não mais situada em face da factualidade democrática como o bom modelo diante do simulacro mortal, mas como o segredo de vida, e de morte, enrolado no cerne mesmo de qualquer demonstração política. A meta-política é o discurso sobre a falsidade da política que vem duplicar cada manifestação política do litígio, para provar seu desconhecimento de sua própria verdade, marcando a cada vez a distância entre os nomes e as coisas, a distância entre a enunciação de um logos do povo, do homem ou da cidadania e o cálculo que dele é feito, a distância reveladora de uma injustiça fundamental, ela mesma idêntica a uma mentira constitutiva. (RANCIÈRE, 1996, p. 89)

A meta-política apaga a política e a define como falsidade, sustentada pelo argumento da igualdade. Ao desvelar que a falsidade move a política ao promover a distância entre as realidades, compara a aparência e a realidade e expõe o litígio do povo. A distância é constitutiva da política e demonstra um povo dividido: o da representação jurídico-política e o do movimento social, que deixa clara a falsa igualdade da democracia. Ranciére faz perceber que a sociedade é marcada pelo dano, pelo litígio, por meio da "partilha do sensível". Esse litígio expressa-se pela fala quando uma parte da comunidade (o demos) se coloca como igual às outras partes, que assim não a consideram.

Em nossa pesquisa podemos relacionar o texto jurídico da lei $\mathrm{n}^{\mathrm{o}} 6583$ de 29 de setembro de 2008 e as enunciações presentes nos posts dos blogs para compreender o litígio/o desentendimento que ocorre entre os internautas (representantes do demos) e a esfera jurídica, representante do poder estatal e de algumas partes da comunidade. A lei trabalha com uma falsa igualdade, uma vez que a legislação refere-se ao conjunto de normas de uma nação e, portanto, deveria representar legalmente toda a nação. Mas a lei aqui analisada determina algo que deve ser seguido por todos, apesar de uma parte não concordar com o que é legislado. Portanto, a lei hierarquiza, segrega, divide e também contribuiu para a manutenção do desentendimento e da parcela dos sem-parcela, que não têm direito à palavra e que não está representada pela legislação. Estamos diante de uma "distância entre a inscrição igualitária da lei e os espaços em que a desigualdade faz lei" (RANCIÈRE, 1996, p. 96). Produz-se um espaço polêmico em que se mantêm juntas a igualdade e a sua ausência, ou seja, produzse o não-lugar do texto jurídico, o qual, a partir do fingimento, é enunciado como igualitário. Nesse "jogo meta-político da aparência e de seu desmentido, a política democrática opõe essa prática do como se que constitui as formas de aparecer de um sujeito e que abre uma comunidade estética (...) que exige o consentimento daquele mesmo que não a reconhece" (RANCIÈRE, 1996, p. 96). Há o falseamento da realidade. E vivencia-se o desentendimento/o dano, pois os sem-parcela não possuem o logos. Eles estão presentes na interlocução instituída pelo discurso jurídico, mas sua voz não tem poder de manifestação - é apenas "ruído". Temos, então, o desvelar da falsa igualdade da democracia, a qual separa a sociedade entre o povo da representação jurídico-política e o do movimento social. A manifestação desse desentendimento pode ser visto e analisado nos posts dos blogs, espaço em que os sem-parcela representam o seu dizer e procuram assumir a palavra (o logos) ao demonstrarem o seu descontentamento diante do Acordo Ortográfico de 1990. 


\title{
3. O POLÍTICO EM GUIMARÃES
}

Guimarães (2005), para conceituar o político (ou a política) a partir de uma perspectiva semântica e enunciativa, estabelece relações com dois teóricos materialistas: Ranciére (1996) e Orlandi (1990). Considerar o político em relação à linguagem é entender que uma palavra em um enunciado ou em um texto pode sempre apresentar outros sentidos, os quais se dividem e derivam para outros sentidos, que estão em conflito.

Guimarães retoma os conceitos de arqui-política, meta-política e para-política apresentados por Rancière e estabelece a relação do político com a produção dos sentidos. Segundo Guimarães (2005), a arqui-política caracteriza a política como mentira. Ela organiza a sociedade através da distribuição de papéis sociais, mas o povo continua sendo a parcela dos sem-parcela, dos desiguais. A para-política trata a política como aparência, pois procura neutralizar o conflito entre pobres e ricos, que possuem interesses diferentes. O seu objetivo é a pacificação social. A meta-política entende a política como a manifestação da falsidade e denuncia as mentiras, as injustiças e as desigualdades em relação ao que a política enuncia. Para Guimarães (2005), essas três formas de perceber a política a apreendem enquanto a prática do falso, do aparente. Mas esse autor irá tratá-la fora dessas concepções negativas para entendê-la como fundamento das relações sociais, tendo a linguagem lugar central em seu pensamento.

Para Guimarães

\begin{abstract}
O político, ou a política, é (...) caracterizado pela contradição de uma normatividade que estabelece (desigualmente) uma divisão do real e a afirmação de pertencimento dos que não estão incluídos. Deste modo o político é um conflito entre uma divisão normativa e desigual do real e uma redivisão pela qual os desiguais afirmam seu pertencimento. Mais importante ainda (...) é que deste ponto de vista o político é incontornável porque o homem fala. O homem está sempre a assumir a palavra, por mais que esta lhe seja negada. (GUIMARÃES, 2005, p. 16)
\end{abstract}

O político é essa contradição presente no dizer que se dá a partir da divisão desigual do real estabelecida pelas formas de organização da sociedade. "Ele se constitui pela contradição entre a normatividade das instituições sociais que organizam desigualmente o real e a afirmação de pertencimento dos não incluídos (GUIMARÃES, 2005, p. 17). Há essa divisão normativa do real pelas instituições sociais e sua redivisão quando o povo (a parcela dos excluídos) afirma o seu pertencimento no todo social. O político é esse conflito, essa afirmação da igualdade, do pertencimento do povo à sociedade, que se encontra em conflito com a divisão desigual do real. Guimarães (2005), a partir dessa conceituação do político, irá olhar para a enunciação. $\mathrm{O}$ acontecimento enunciativo é visto como político, pois constitui os sentidos. Esses sentidos se dividem, entram em conflito, apagam-se, ao constituir os sujeitos e organizar seus lugares enunciativamente de forma desigual.

A compreensão da política como desentendimento presente na cena enunciativa possibilita analisar, a partir do acontecimento enunciativo tomado por Guimarães (2005), o funcionamento do político em nosso corpus. Podemos, 
então, avaliar o que a palavra designa e o modo como os sentidos circulam no funcionamento textual a partir do conflito e do litígio, das contradições e dos apagamentos nos sentidos presentes na expressão "acordo ortográfico" em posts dos blogs e no decreto $\mathrm{n}^{0} 6583$ de 29 de setembro de 2008. Através dessas reflexões, nos propomos tratar a linguagem enquanto enunciação, ao olhar para seu caráter dinâmico e pensar o sentido como múltiplo, como possibilidade de ser sempre outro.

\section{O POLÍTICO NO ÂMBITO JURÍDICO: DECRETO Nº 6583/08}

O político está presente na decretação de acordos ortográficos por serem práticas institucionais sobre a língua. Nessa perspectiva, nos propomos a analisar os sentidos que perpassam a expressão "acordo ortográfico" para entendermos as suas especificidades semânticas. No trecho abaixo:

Considerando que o projeto de texto de ortografia unificada de língua portuguesa aprovado em Lisboa, em 12 de outubro de 1990, pela Academia das Ciências de Lisboa, Academia Brasileira de Letras e delegações de Angola, Cabo Verde, Guiné-Bissau, Moçambique e São Tomé e Príncipe, com a adesão da delegação de observadores da Galiza, constitui um passo importante para a defesa da unidade essencial da língua portuguesa e para o seu prestígio internacional (BRASIL, Lei $\mathrm{n}^{\circ} 6.583$, de 29 de setembro de 2008)

No recorte acima, observamos que, no acontecimento enunciativo da Lei $n^{\circ} 6583 / 08$, a língua portuguesa é determinada por: ortografia unificada, unidade essencial e prestígio internacional. O político, nesse recorte, funciona ao tratar a língua como única no domínio internacional e, consequentemente, produz apagamentos e silenciamentos no que diz respeito às variantes da língua portuguesa.

Em outro recorte:

\footnotetext{
Art. $2^{\circ}$. Os Estados signatários tomarão, através das instituições e órgãos competentes, as providências necessárias com vista à elaboração, até 1 de janeiro de 1993, de um vocabulário ortográfico comum da língua portuguesa, tão completo quanto desejável e tão normalizador quanto possível, no que se refere às terminologias científicas e técnicas. (BRASIL, Lei n ${ }^{\circ} 6.583$, de 29 de setembro de 2008)
}

A elaboração de um "vocabulário ortográfico comum da língua portuguesa" reforça no texto da lei seu caráter homogêneo. Novamente a língua é normatizada e entendida como única nos diferentes países falantes do português. A ortografia da língua torna-se regulamentada pelo decreto e apagam-se, por meio do vocabulário comum da Língua Portuguesa, as diferenças ortográficas de cada nação.

No Anexo II da Lei no 6583/08 há uma "Nota explicativa do Acordo Ortográfico da Língua Portuguesa" composta de oito subtítulos: (1) Memória breve dos acordos ortográficos; (2) Razões dos fracassos dos acordos ortográficos; (3) Forma e substância do novo texto; (4) Conservação ou supressão das consoantes $c, p, b, g, m$ e $t$ em certas seqüências consonânticas (Base IV); (5) Sistema de acentuação gráfica (Bases VIII a XIII); (6) Emprego do hífen (Bases 
XV a XVIII); (7) Outras alterações de conteúdo; (8) Estrutura e ortografia do novo texto. Acreditamos ser importante analisar o anexo, pois trata de considerações complementares ao texto da lei.

No subtítulo 1, intitulado "Memória breve dos acordos ortográficos", no primeiro parágrafo, lê-se:

A existência de duas ortografias oficiais da língua portuguesa, a lusitana e a brasileira, tem sido considerada como largamente prejudicial para a unidade intercontinental do português e para o seu prestígio no Mundo. (BRASIL, Lei $\mathrm{n}^{\circ} 6.583$, de 29 de setembro de 2008)

Nota-se que ocorre a retomada da justificativa já presente no texto da lei para a unificação da ortografia da Língua Portuguesa, uma vez que "a existência de duas ortografias oficias" é vista como "largamente prejudicial" para a "unidade intercontinental" e para o seu "prestígio no Mundo". Busca-se apagar, através do Acordo Ortográfico, as desigualdades entre a ortografia oficial lusitana e a brasileira, por ser vista como algo prejudicial à própria Língua Portuguesa. Temse, então, a tentativa do Estado de silenciar essas diferenças através do poder que se materializa no texto da lei, que deve ser cumprida por todos os falantes da Língua Portuguesa pertencentes aos países signatários ao acordo. Impõese uma ação homogeneizadora através do caráter normativo da lei. Cria-se um espaço enunciativo mundial normatizado, supostamente igual do ponto de vista legislativo, para os falantes do português. E, por meio desse dizer normatizado, organiza-se o social e produz-se o conflito entre a divisão normativa do real e a redivisão na qual os desiguais afirmam seu pertencimento. O político põe em funcionamento a linguagem, pois nele os sentidos se constituem, se dividem e redividem, apagam-se, entram em conflito, constituindo os sujeitos e distribuindo seus lugares na enunciação de maneira desigual.

No subtítulo 2: "Razões do fracasso dos acordos ortográficos" nos dois últimos parágrafos encontramos os seguintes enunciados:

\footnotetext{
Nestas condições, há que procurar uma versão de unificação ortográfica que acautele mais o futuro do que o passado e que não receie sacrificar a simplificação também pretendida em 1986, em favor da máxima unidade possível. Com a emergência de cinco novos países lusófonos, os fatores de desagregação da unidade essencial da língua portuguesa far-se-ão sentir com mais acuidade e também no domínio ortográfico. Neste sentido importa, pois, consagrar uma versão de unificação ortográfica que fixe e delimite as diferenças atualmente existentes e previna contra a desagregação ortográfica da língua portuguesa.

Foi, pois, tendo presentes estes objetivos, que se fixou o novo texto de unificação ortográfica, o qual representa uma versão menos forte do que as que foram conseguidas em 1945 e 1986. Mas ainda assim suficientemente forte para unificar ortograficamente cerca de $\mathbf{9 8 \%}$ do vocabulário geral da língua. (BRASIL, Lei $\mathrm{n}^{\circ} 6.583$, de 29 de setembro de 2008)
}

Nesse recorte reitera-se a unificação da língua através da ortografia, justificada por meio da simplificação. A preocupação enunciada no texto voltase para "consagrar uma versão de unificação ortográfica que fixe e delimite as diferenças atualmente existentes e previna contra a desagregação ortográfica da 
língua portuguesa". O caráter homogeneizador da ação do Estado se faz presente novamente, uma vez que a lei consegue unificar "cerca de 98\% do vocabulário geral da língua". Temos aí o funcionamento do político como demonstra Rancière ao citar a meta-política: com a unificação da língua mostra-se a falsidade que há na política, que se sustenta pelo argumento de igualdade. Há uma distância entre o real da língua e a legislação. A lei estabelece desigualmente a divisão do real e, ainda, afirma o pertencimento dos que não estão incluídos. O político é visto como o conflito entre uma divisão normativa e desigual do real e uma redivisão pela qual os desiguais afirmam seu pertencimento. Para observarmos esse processo conflituoso, na sequência, apresentamos o funcionamento do político nos blogs que versam sobre o Acordo Ortográfico.

\section{O POLIITICO NA INTERNET: OS POSTS EM BLOGS SOBRE O ACORDO ORTOGRÁFICO DE 1990}

Iniciamos as análises com posts do blog "Viamão Lotado: um metablogue de peso". Essa página da internet é de autoria de três brasileiros. Os posts aqui analisados surgiram a partir do texto "Reforma ortográfica pega de surpresa os analfabetos!" publicado em outubro de 2008. No primeiro recorte temos:

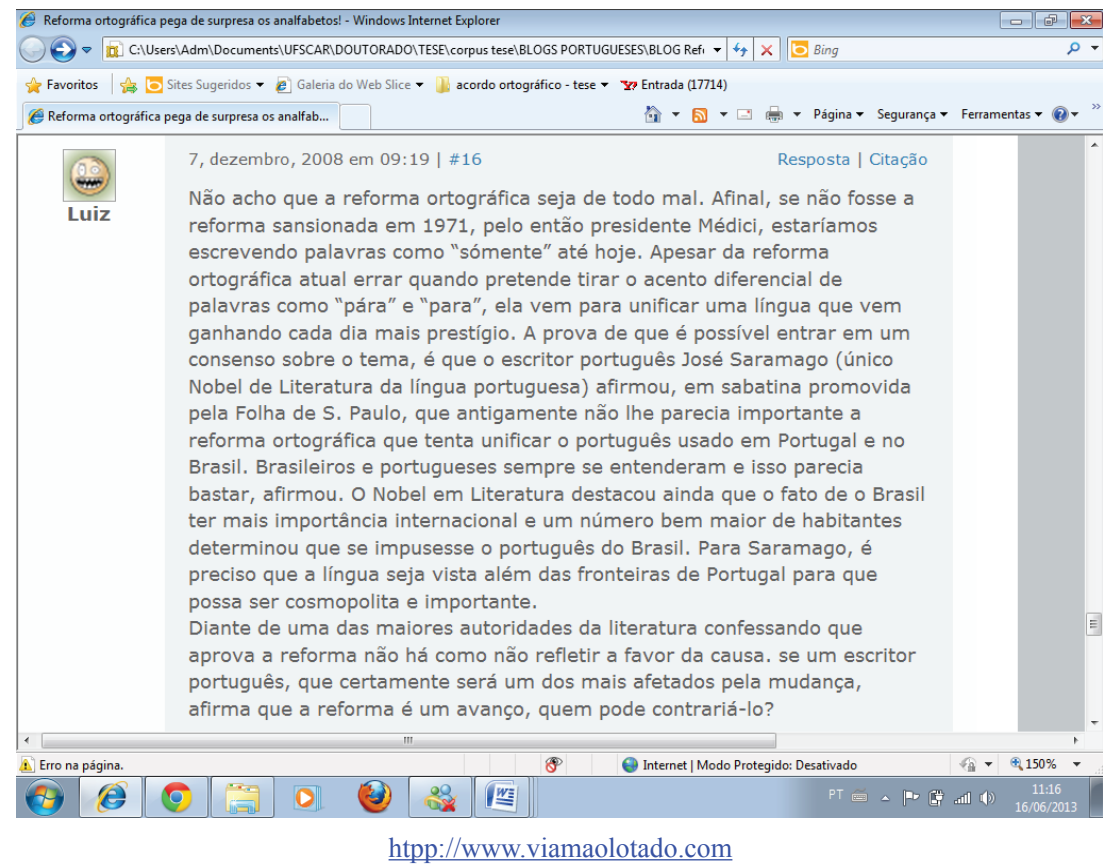

Nesse post destacamos que o enunciador do blog assume a posição favorável ao Acordo Ortográfico. A primeira frase do post já mostra sua opinião: "Não acho que a reforma ortográfica seja de todo mal". Para endossar sua posição, recorre ao 
argumento de autoridade e menciona o escritor português José Saramago - "único Nobel de Literatura da língua portuguesa" - como favorável ao acordo. Podemos nesse post recuperar o memorável da homogeneidade e da unificação presente no texto de lei do Acordo Ortográfico de 1990 e, também, presente na Reforma ortográfica de 1911 ocorrida apenas em Portugal. Temos "unificar" e "avanço" predicando "reforma ortográfica", a qual apresenta uma relação de sinonímia com "Acordo Ortográfico". Portanto, o enunciador é agenciado pela posição do Estado e enuncia a partir daí. Nessa perspectiva, há uma das formas de funcionamento do político ao buscar-se produzir o efeito de consenso e apagar o diferente na relação entre línguas, quando se demonstra que a maior preocupação é com a "unificação" para que a língua portuguesa "possa ser cosmopolita e importante".

Ao considerarmos outro post realizamos o seguinte recorte:

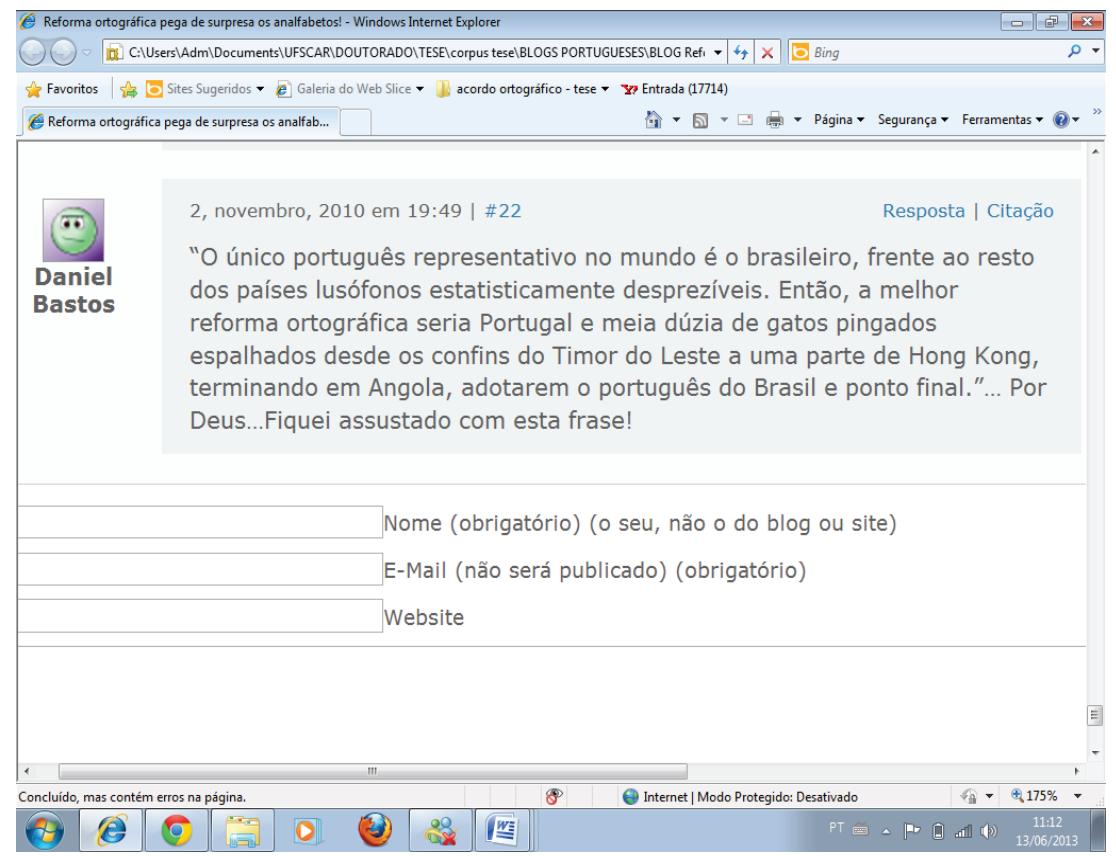

htpp://www.viamaolotado.com

O post acima inicia com uma fala aspeada, que foi retirada do texto intitulado "Reforma ortográfica pega de surpresa os analfabetos!" e que originou outros comentários presentes no blog. Nessa fala temos a língua portuguesa considerada a partir do português brasileiro: "o único português representativo no mundo é o brasileiro". Notamos aqui uma hierarquização da língua: o português brasileiro é considerado soberano em relação ao português europeu. Essa hierarquização na relação entre línguas é outra forma do político funcionar, que é marcada pela divisão e disputa pelo dizer, no espaço do dizer. Essa hierarquização gera, também, a desigualdade na relação entre línguas. 
Os posts seguintes foram retirados do blog português: "ILC contra o acordo ortográfico: ler, assinar, divulgar". A sigla ILC refere-se à "Iniciativa Legislativa de Cidadãos contra o Acordo Ortográfico”. O blog concentra informações sobre essa iniciativa, tendo sido criado por um grupo informal de cidadãos mobilizados enquanto sociedade civil em prol da defesa da Língua Portuguesa em suas cambiantes culturais. O grupo opõe-se ao acordo por afirmar que o mesmo age contra a identidade coletiva, o patrimônio cultural e a história da língua.

No primeiro recorte temos:

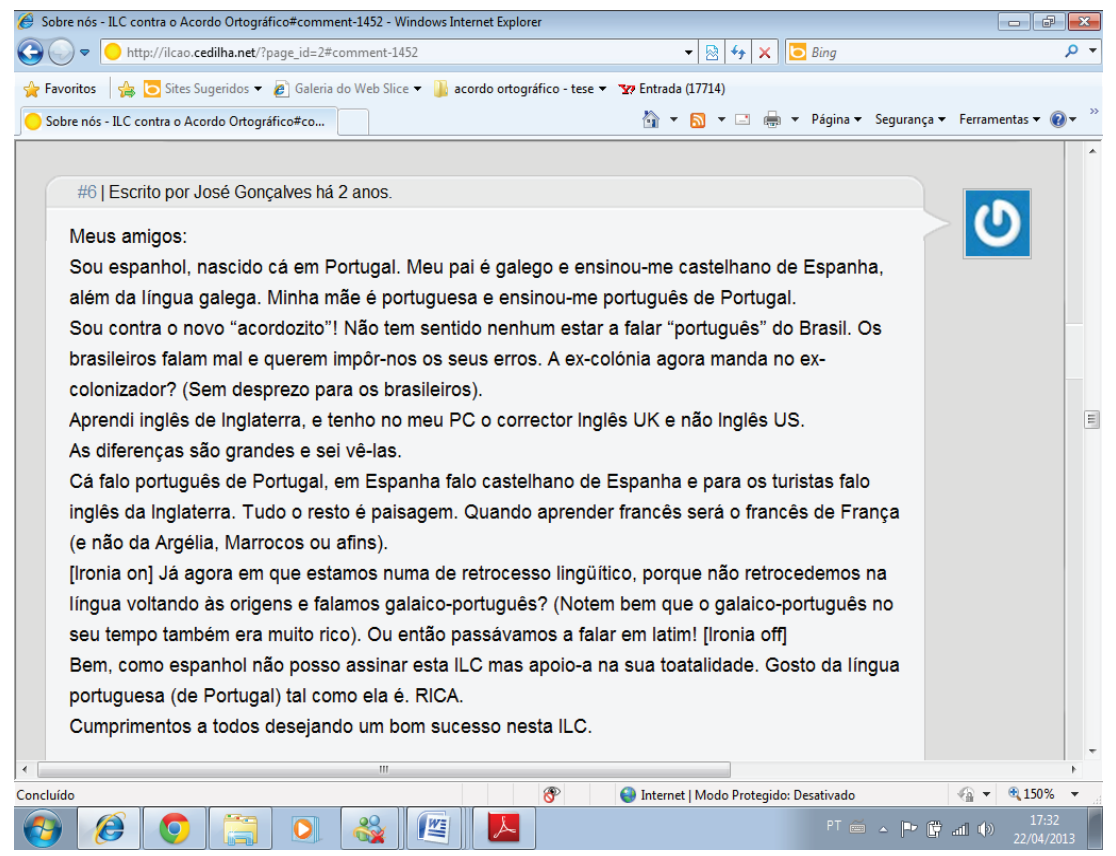

http://decaedela.blogspot.com/2010/01/por-que-sou-favor-do-acordo-ortografico.html

O locutor, ao enunciar "Sou contra o novo 'acordozito"!” e “...como espanhol não posso assinar esta ILC, mas apoio-a na sua toatalidade (sic)", está no lugar de dizer de enunciador individual na $1^{a}$ pessoa do singular. Essas enunciações demonstram que o locutor leu o blog e apresenta a mesma posição ideológica aí defendida: é contrário ao Acordo Ortográfico de 1990.

O termo "acordozito" grafado entre aspas induz o leitor a compreender uma diminuição irônica e pejorativa para "acordo ortográfico", ao determiná-lo. O enunciador ao afirmar: "Sou contra o novo "acordozito"! revela sua posição explicitamente. A sequência: "Não tem sentido nenhum estar a falar "português" do Brasil. Os brasileiros falam mal e querem impôr-nos os seus erros", pode ser parafraseada por:

a" "O acordo ortográfico tem por base o português do Brasil"

a" "O acordo ortográfico impõe aos lusos o português do Brasil"

a"" "O acordo ortográfico tem por base os erros do português do Brasil" 
Por meio dessas paráfrases, podemos dizer que "português do Brasil” predica acordo ortográfico, o qual, segundo o enunciador sofre grande influência negativa do português falado pelos brasileiros. O enunciado: "A ex-colônia agora manda no ex-colonizador? (Sem desprezo para os brasileiros)", retoma no fio discursivo o memorável da colonização lusitana ao destacar a relação entre país colonizador e colonizado através do papel da língua. Dessa forma, retoma a posição histórica de cada país no processo de colonização: Portugal, o colonizador independente, representando um grande centro cultural que possui o poder econômico, político e social. E Brasil, o colonizado, dependente de um sistema neocolonial e submisso às leis lusas. Nesse cenário, do ponto de vista do enunciador, torna-se inaceitável uma inversão de valores, a partir dos quais o português do Brasil determina regras para o acordo ortográfico que também será seguido pelos lusitanos. O enunciador do post fala do lugar de colonizador ao usar a antonímia: colonizador x colonizado. Nessa relação entre línguas, o político se faz presente, uma vez que o enunciador retoma o memorável da norma da língua ao diferenciar o português de Portugal e o português do Brasil. Esse enunciador do post constitui-se pelo litígio ao se referir à língua portuguesa e às demais línguas, conforme podemos observar nos enunciados:

Aprendi Inglês da Inglaterra, e tenho no meu PC o corrector Inglês UK e não Inglês US.

As diferenças são grandes e sei vê-las.

Nesse enunciado, o político faz-se presente novamente ao hierarquizar a língua, sendo o inglês britânico considerado superior ao inglês americano. A expressão "retrocesso lingüístico" reescritura por especificação "acordo ortográfico" no enunciado. E adjetiva pejorativamente o acordo ao empregar o termo "retrocesso", que significa decadência, algo obsoleto.

Os posts seguintes que integram nossas análises pertencem ao blog angolano Deprofundis. Essa página da internet declara-se um espaço de combate aos abusos de poder originários das diferentes esferas sociais. Portanto, trata de vários assuntos: religião, política, cultura, língua portuguesa e, entre outros temas, versa também sobre o acordo ortográfico. O post a seguir foi publicado em março de 2013 e gerado a partir do texto: “O Brasilês - Acordo Ortográfico: não obrigado". 
Cadernos de ESTUDOS LINGüIISTICOS (56.2) - Jul./Dez. 2014

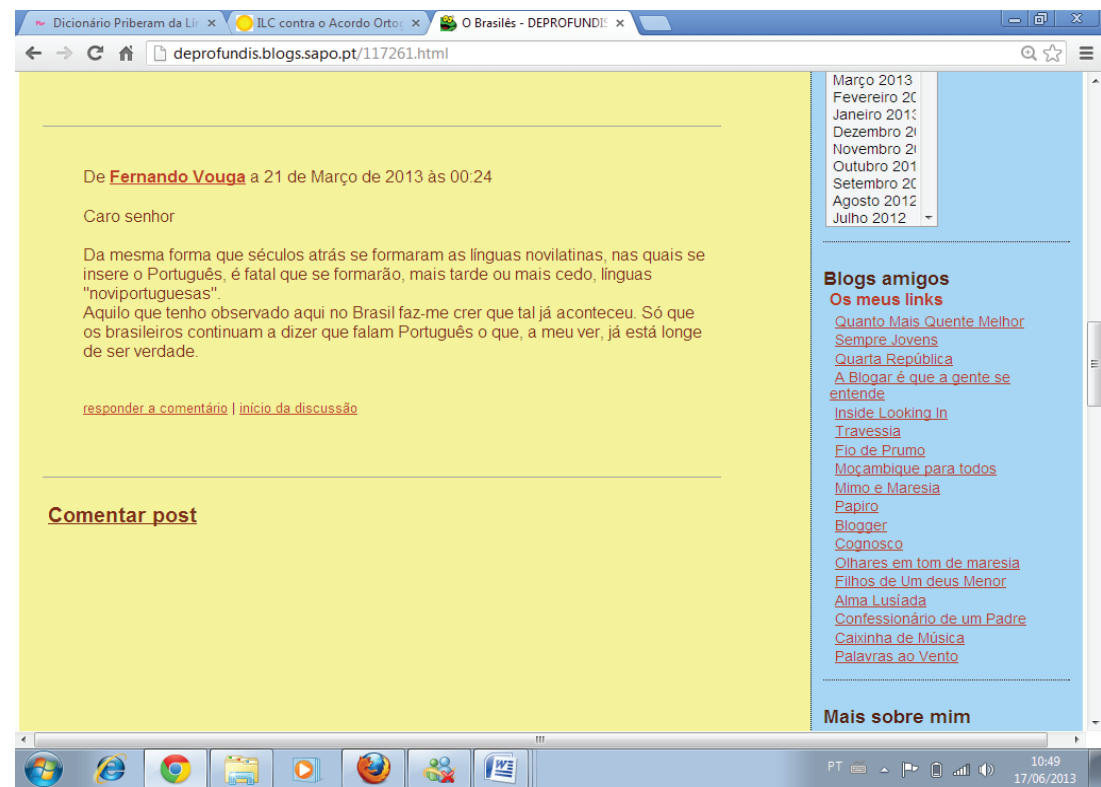

http://deprofundis.blogs.sapo.pt/117261.html

Nesse post, a língua portuguesa é descrita a partir dos padrões linguísticos europeus. Podemos observar essa situação quando o enunciador afirma: “... os brasileiros continuam a dizer que falam Português o que, a meu ver, já está longe de ser verdade". Em outro post ocorre o mesmo procedimento:

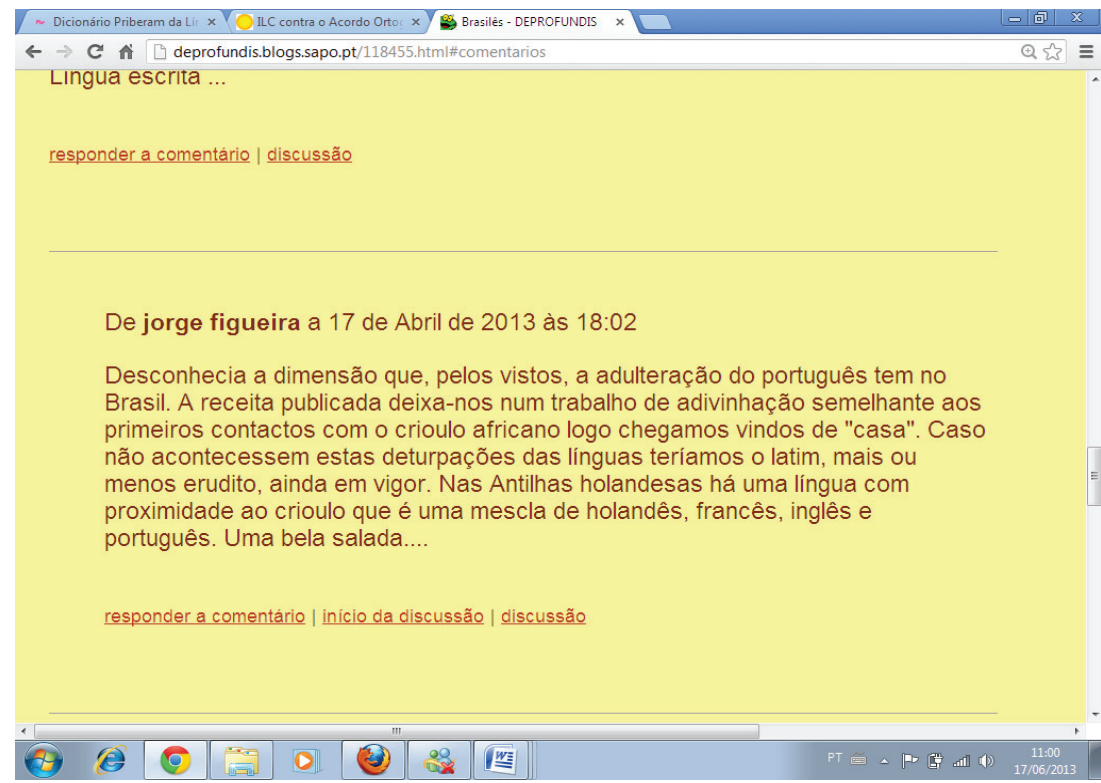

http://deprofundis.blogs.sapo.pt/118455.html\#comentarios 
Receita $^{2}$

O enunciador afirma: "desconhecia a dimensão que, pelos vistos (sic), a adulteração do português tem no Brasil”. A língua portuguesa novamente é tratada a partir dos padrões europeus. Temos o político funcionando por meio dessa hierarquização no espaço do dizer. Há a não-inclusão dos falantes da língua portuguesa brasileira no espaço enunciativo da língua portuguesa. Destacamos que, na relação entre línguas, o português europeu é entendido como superior ao português brasileiro. O político divide desigualmente as línguas. Essa relação no texto da lei é descrita como consensual, ao apagar-se o conflito. Entretanto, nos posts o conflito é abordado de forma clara e objetiva, colaborando para a perpetuação da hierarquização e do dissenso.

\section{ALGUMAS CONSIDERAÇÕES}

Enquanto texto de lei, o Acordo Ortográfico de 1990 produz um efeito de consenso no litígio, o qual se dá através do funcionamento do político. Esse efeito só é possível, porque há um apagamento das relações históricas e políticas entre a língua portuguesa e seus falantes. Ambos são representados na lei em uma enunciação universal, marcada pela relação harmônica entre os países lusófonos e os seus falantes. Apaga-se o conflito, a relação hierarquizada e normativa verificada entre os usuários da Língua Portuguesa, pois o texto de lei do Acordo Ortográfico trata a língua como homogênea. E, ainda, afirma o pertencimento dos não-incluídos ao produzir silenciamentos e apagamentos.

Entretanto, esse apagamento pode ser recuperado nos posts dos blogs referentes ao acordo da Língua Portuguesa, por se tratar de um espaço não institucionalizado pelo Estado e que escapa à esfera jurídica. Na cena enunciativa dos posts, observamos o leitor do blog afirmando seu pertencimento no espaço do dizer. Temse a movimentação do político no momento em que cada enunciador do blog, através dos posts, assume a palavra e expõe sua posição diante do acordo ortográfico. O blog torna-se, nessa perspectiva, um meio para os excluídos buscarem sua inclusão.

Ao longo das análises, verificamos o funcionamento do político de diferentes formas: a primeira é através do apagamento e do silenciamento das diferenças entre a língua portuguesa europeia e a brasileira, ao gerar a ideia de unificação e homogeneização da língua. Essa posição corrobora a posição presente no texto de lei do Acordo e endossa a enunciação do Estado. Outra forma do político movimentar-se no corpus analisado é através da hierarquização das línguas, a partir da qual a língua portuguesa europeia é considerada melhor que a língua portuguesa brasileira, ou vice-versa.

${ }^{2}$ A receita citada no post segue transcrita: "Recei di Repôi Picadim”. Ingridienti: 5 den di ái; 3 cuié di oi; 1 cabêss di repôi; 1 cuié di mastumati; Sali a gosto. Mé qui faiz!?: Casca u ái; pica u ái e soca u ái cum Sali. Quenta u oi; foga o ái nu oi quentim. Pica o repôi bemmm finimn, foga o rêpoi. Poim a mastumati mexi Ca cuié pra fazê o moi. Prontim". A receita traz como nota a seguinte firmação "Sem grandes exageros, posso afirmar que há muita gente no Brasil que escreve assim..." (http://deprofundis. blogs.sapo.pt/118455.html) 


\section{REFERÊNCIAS BIBLIOGRÁFICAS}

BRASIL. Ministério das Relações Exteriores. Decreto $\mathbf{n}^{\mathbf{0}}$ 6583, de 29 de setembro de 2008. Promulga o Acordo Ortográfico de Língua Portuguesa, assinado em Lisboa, em 16 de dezembro de 1990. Brasília, 2008.

GUIMARÃES, Eduardo. Semântica do Acontecimento. Campinas, SP: Pontes, 2005.

ILC CONTRA O ACORDO ORTOGRÁFICO: LER, ASSINAR, DIVULGAR. Disponível em: http:// ilcao.cedilha.net/?page id=2\#comment-1452, Acesso em: 30. jun 2012.

MALTA, Isaías. Reforma ortográfica pega de surpresa os analfabetos! In: Viamão Lotado: um metablogue de peso. <htpp://www.viamaolotado.com> Acesso em 13 jul 2013.

ORLANDI, Terra à vista!: discurso do confronto: velho e novo mundo. São Paulo: Cortez. Ed. Da Unicamp, 1990.

RANCIÈRE, J. O desentendimento: política e filosofia. São Paulo: Editora 34, 1996.

VOUGA, Fernando. O Brasilês. In: Deprofundis. <http://deprofundis.blogs.sapo.pt/117261.html > Acesso em 17 jul 2013. 